Asia Pacific Journal of Education, 34 (4), 2014.

\title{
Understanding the nexus between mainstream schooling and private supplementary tutoring: patterns and voices of Hong Kong secondary students
}

\author{
Ora Kwo $^{\mathrm{a} *}$ and Mark Bray ${ }^{\mathrm{a}}$ \\ ${ }^{a}$ Faculty of Education, The University of Hong Kong, China
}

(Received 15 August 2013; Final version received 20 June 2014)

\begin{abstract}
While research is increasingly available on the scale and costs of private supplementary tutoring, less information focuses on its pedagogical dimensions. This paper addresses patterns in Hong Kong. The paper begins with the quantitative picture solicited through questionnaires for students in Grades 9 and 12, and then turns to data from interviews.

Among the students, some received tutoring while others did not. Those who received tutoring were asked to compare their teachers and tutors, and to indicate what they sought from the tutors that they did not find in their schooling. The students who did not receive tutoring were also asked about the culture of tutoring, and whether they would have liked to have received tutoring if they had had the necessary financial resources. Especially pertinent were statements about learning gaps and ways in which tutoring was perceived to help.

The themes of this paper may resonate widely. The paper shows that students' learning objectives may differ from those of their teachers, and comments on the implications of these patterns for wider processes of government-led reform. The paper helps to explain how wellintentioned top-down innovations may be subverted by conflicting expectations and the divergent agendas of students, teachers and tutors.
\end{abstract}

Keywords: private tutoring, shadow education, teachers' roles, pedagogy, learning orientations

\section{Introduction}

Around the world, increasing numbers of students receive out-of-school private tutoring (Aurini, Davies \& Dierkes, 2013; Bray, 2009; Mori \& Baker, 2010). In its academic form, this is widely called shadow education because much of its content mimics that of mainstream schooling. Thus, when the authorities change the curriculum in the mainstream schools, before long it changes in the shadow. However, other components in the private tutoring curriculum supplement rather than mimic the curriculum of mainstream schooling.

Although private tutoring has long been very visible in much of East and South Asia, researchers have been slow to focus on the phenomenon. A few publications can be cited from the 1980s and 1990s (e.g. Bray, 1999; Hemachandra, 1982; Marimuthu et al., 1991; Stevenson \& Baker, 1992), but significant expansion of the literature has only occurred since the turn of the century (e.g. Aslam \& Atherton, 2014; Dawson, 2010; Kwok, 2001). Much of the literature, both on Asia and on other parts of the world (e.g. Bray, Mazawi \& Sultana, 2013; Silova, Būdienė \& Bray, 2006), has focused on the scale of tutoring and on its economic and social implications. Relatively little has focused on relationships between private tutoring and mainstream schooling, which is the focus of this paper.

Hong Kong is among the societies with particularly high rates of private tutoring. The 2011/12 survey reported in this paper found that $61.1 \%$ of sampled Grade 9 and

\footnotetext{
*Corresponding author. Email: wykwo@hku.hk
} 
Grade 12 students had received private supplementary tutoring during the previous 12 months. Those figures were obtained from a questionnaire survey which was accompanied by individual interviews. The present paper summarises data from the questionnaires and elaborates on findings from the interviews. It begins with broad literature that sets a conceptual framework before turning to the specifics of Hong Kong and its education system. The paper then outlines the ways in which data were collected, following which it presents the views of students on the relationships between their tutoring and their mainstream schooling. The concluding section returns to the wider framework to show the significance of the paper.

\section{A conceptual framework}

An overall question and starting point for this paper concerns the aims of education as perceived not only by governments and education authorities but also by parents and students. Perspectives do not always converge, and sometimes the strategies used by parents and students to achieve their aims undermine the objectives of governments and education authorities. Thus, many international and national documents espouse the goals of creativity, lifewide learning, and development of social harmony (e.g. People’s Republic of China, 2010; Delors, 1996; Faure, 1972; Hong Kong Education Commission, 2006). Parents and students may see value in these objectives in principle, but are also greatly concerned about competition and pathways to desirable openings at higher levels of education and then to forms of employment. In many education systems, this requires close attention to examinations set internally by schools at each grade and externally at various points and particularly the end of secondary schooling (Ho, 2012; Zeng, 1999).

The $20^{\text {th }}$ century was characterised by the rise of government-sponsored systems of education which were financed by taxes and other sources of public revenue. The Universal Declaration of Human Rights (United Nations, 1948, Article 26) declared that everyone has the right to education and set the stage for expanded government provision. The following decades brought massive development of school systems with the goals first of universal primary education, then of universal lower secondary education, and then of significantly expanded upper secondary and tertiary education. Governments were seen as the core institutional providers, though in most countries private operators were permitted to provide parallel offerings.

Since the beginning of the $21^{\text {st }}$ century, the role of private operators has expanded. This is not just in the provision of alternatives to the public system but also in provision of supplements. Many families feel that public schooling is by itself not adequate to meet their needs and desires in the competitive environment. The private sector encourages this view, since families then invest in additional services. Education has increasingly been viewed as a marketable service (Burch, 2009; Verger \& Robertson, 2012). This trend has relevance to private supplementary tutoring as well as to private institutions that offer alternatives to public ones.

Further complexities arise from the fact that private tutoring is rarely just a supplement that leaves the school system itself unchanged. More commonly, private tutoring has a backwash on school systems (see e.g. Dohmen et al., 2008; Hamid et al., 2009; Odhiambo, 2009). In some cases the backwash is positive: children who have been lagging behind are able to catch up with their peers and comprehend lessons more effectively with the additional support. In these situations, the tutoring may reduce inequalities in the classroom, and make the teacher's work easier. In other cases, the backwash is negative. Children who spend many hours in supplementary 
lessons may be tired and operate less effectively in regular lessons. Also, children may pay more attention to tutors to whom they or their families are directly paying money than to their teachers who seem to come not only free of charge but also as an imposition without choice.

With such factors in mind, it is necessary to look at the nexus of mainstream schooling and private tutoring, to identify the nature of relationships. Investigation can highlight not only complementarities but also dissonances, and part of the challenge lies in the tensions between the visible and the less visible (Kennedy, 2005; Kwo, 2010; Schweisfurth, 2013). One question is what the students want and get - or think that they want and get - in the private tutoring that they do not get in their mainstream schooling. A second question is what impact the tutoring has on the regular lessons. The negative backwash of tutoring may extend to students who do not receive tutoring, especially if the teachers assume that external help is available for all and pay less attention to learning difficulties than they would have done had the apparent safety net of the tutoring system not existed. The full set of relationships is complex, and cannot be explored in a single paper even with a restricted geographic remit and focus on just one level of education. Nevertheless, this paper can expose some of the issues, which it chiefly does through identification of the scale and motives for receiving tutoring, and students' perceptions of pedagogic styles and learning orientations at school and in tutoring.

\section{Hong Kong and its education system}

To provide another dimension of the framework for this paper, it is necessary to outline some key features of Hong Kong and its education system. The remarks that follow begin with political, economic and social features before turning to the school system and the parallel provision of private tutoring.

Since 1997, Hong Kong has been governed as a Special Administrative Region of the People's Republic of China. This arrangement gives the Hong Kong authorities autonomy in many domains including currency, law and education. Hong Kong has a population of approximately 7.1 million, among whom 93.4\% are ethnically Chinese (Hong Kong Census \& Statistics Department, 2012, p. 7). Ethnicity has implications for education, including private tutoring, insofar as attitudes are shaped by cultural factors including a Confucian heritage (Kwok, 2004; Salili, 1996). Among the nonChinese population, the largest groups are Indonesians and Filipinos, each comprising about 30\% (Hong Kong Census \& Statistics Department, 2012, p. 7). The next largest group (12\% of non-Chinese) comprises 'Whites', followed by 'Mixed' (6\%). These groups may also seek private tutoring, though may attend international schools that do not follow local curricula and thus have different orientations.

Hong Kong is a prosperous society, which means that most families can afford to invest in at least some private supplementary tutoring if they choose to do so. The 2012 per capita Gross Domestic Product of US\$36,800 was among the highest in Asia (Hong Kong Information Services Department, 2013, p. 37). Nevertheless, within the population are considerable income disparities (Henrard, 2011), and the costs of tutoring may be a burden to some households.

Among the legacies that remain from the British colonial era prior to 1997 is the place of the English language in the education system. English remains an official language alongside Chinese, is taught as a subject in all schools, and is the medium of instruction in some schools. Other educational features have been changed in the postcolonial era. In particular, the Hong Kong government has replaced the $6+5+2+3$ 
structure (i.e. six years of primary, five years of secondary, two years of upper secondary, and three years for a standard university degree) with a $6+3+3+4$ structure. However, the vast majority of students remain in the same institutions for translation from lower to upper secondary. The new structure leads at the end of secondary schooling to the Hong Kong Diploma of Secondary Education (HKDSE) examination, scores in which are the major criterion for university entrance. The first HKDSE examination was held in 2012.

Private supplementary tutoring in Hong Kong is provided through both formal and informal arrangements. On the formal side are companies, some of which operate in chains. Tutoring centres were reported in 2011 to have capacity for 45,700 students of which 54\% was through large companies with multiple outlets and the remainder was through stand-alone enterprises (Synovate, 2011, cited by Modern Education Group, 2011, p. 93). Some of the tutoring is conducted on a one-to-one basis, while other tutoring is in small groups, and the third variation, especially for senior secondary students about to sit the HKDSE examination, is in large classes. Many of the large centres employ tutoring 'kings and queens' (Kwo \& Bray, 2011), who use strategies resembling those of fashion stars and popular musicians to appeal to teenagers.

Alongside the work of these companies is much informal activity. University students and even secondary students commonly provide tutoring as a way to earn pocket money. Other individuals may also work informally as tutors, often without written contracts. These tutors usually teach either one-to-one or in small groups.

\section{Methodology}

The data reported in this paper were collected as part of a study of the scale and implications of tutoring in Hong Kong (see Bray, 2013; Zhan et al., 2013). Sixteen secondary schools, representing $3 \%$ of the total number, were identified by stratified random sampling. Within the schools, two classes each of Grades 9 and 12 were selected to identify schools serving all three ability bands (Band 1 being the highest achievers and Band 3 the lowest) and also including two private schools and one government-aided school serving international students. Consent forms were distributed for the students to take home and gain parental approval, following which the students who brought back the signed consent forms were asked to complete questionnaires. Among the 1,646 questionnaires distributed, 1,624 usable responses were received. Among them, 59.5\% were from Grade 9, and 40.5\% were from Grade 12.

In addition, 101 students were selected for interview. The sampling frame sought balances of boys and girls, and of students with and without tutoring. These balances were largely achieved, though were shifted by the facts that some schools were singlesex institutions and that some schools had such high rates of tutoring that it was difficult to find students who did not receive tutoring. Within the final sample, the gender balance was $48.5 \%$ male and $51.5 \%$ female - though the analysis did not reveal significant differences in patterns between males and females. More interesting were the differences between students who did and did not receive tutoring, of which the respective proportions in the sample were $54.0 \%$ and $46.0 \%$.

The questionnaire data were analysed using SPSS software, and the interview data using NVivo software. All interview responses were coded, and a structure of nodes was set up for clustering the themes mentioned by students. Iterative review of data in various combinations generated preliminary patterns. The focus for further analysis emerged from refinement in understanding of students' perspectives in terms of both 
recurrent emphases and succinct articulation.

Students' perceptions of the variations in pedagogic styles and learning orientations were considered the most significant components for the present paper. The juxtapositions of experiences from mainstream schooling and private supplementary tutoring presented here result first from quotations being slotted into columns for initial analysis and further review, and second from reconstruction of articulation with merged voices. This process permitted classification of data in meaningful patterns while retaining the authenticity of the respondents' voices.

\section{The scale and motives for receiving tutoring}

As indicated above, among the sample of respondents to the questionnaire, $61.1 \%$ of sampled Grade 9 students and Grade 12 students reported that they had received private tutoring during the previous 12 months. Table 1 records the students' reported motives for taking or not taking tutoring. Respondents were invited to select all categories that were pertinent, and to identify additional reasons if their motives had not been fully covered by the preceding list. Improvement of examination scores was by far the dominant motive. Next in the scale of motives was the allied category of learning school subjects better. One third of the students who received tutoring indicated that their parents had chosen the activity for them, and one fifth said that they went to tutoring because many of their friends did so.

Table 1. Students' Motives for Taking or Not Taking Private Tutoring, Hong Kong

\begin{tabular}{lc}
\hline Motives for taking private tutoring & Percentage of students \\
\hline To improve examination score & $83.9 \%$ \\
To learn school subjects better & $71.5 \%$ \\
My parents chose it for me & $32.7 \%$ \\
Many of my friends are doing it & $19.3 \%$ \\
My teachers recommended it & $7.6 \%$ \\
Attracted by advertisement & $1.5 \%$ \\
Other reasons & $4.3 \%$ \\
\hline Number & 992 \\
\hline Motives for not taking private tutoring & Percentage of students \\
\hline I don't have time & $35.8 \%$ \\
It is not worth the money & $27.7 \%$ \\
None of the available private tutoring seems to suit my & \\
needs & $26.7 \%$ \\
My teachers are knowledgeable enough & $26.1 \%$ \\
I don't have the money & $23.7 \%$ \\
I'm already doing well enough in school & $17.2 \%$ \\
Not many of my friends are doing it & $9.9 \%$ \\
My parents do not want me to do it & $6.8 \%$ \\
My teachers said it is not useful & $4.4 \%$ \\
Other reasons & $15.1 \%$ \\
\hline Number & 632 \\
\hline
\end{tabular}

Source: Zhan et al. (2013, p. 502).

On the other side, about one third of the students who did not receive tutoring 
indicated that it was because they did not have the time. Just over a quarter indicated that they did not consider tutoring worth the money, and a similar proportion indicated that none of the available private tutoring seemed to suit their needs. An equivalent proportion, which at a quarter is perhaps strikingly low, indicated that they considered their teachers knowledgeable enough; and $17.2 \%$ indicated that they did not receive tutoring because they were already doing well enough in school.

Subsequent commentary in this paper is related to the roles of teachers. Only $7.6 \%$ of the students receiving tutoring indicated that they did so because their teachers had recommended it; and only $4.4 \%$ of the students who did not receive tutoring indicated that they did not do so because the teachers said that it was not useful. This suggests that few teachers actively guided students towards or away from tutoring. Students and their family members thus appeared to make their own decisions, based on appraisal of their needs and available options.

\section{Pedagogic styles}

A major element in the context within which students and their families decided to seek tutoring concerned the respective pedagogic styles of teachers and tutors. Table 2 presents extracts from the interview data on perceptions of these styles. First it contrasts remarks by students about the content of learning at school and the skills acquired in tutoring; and second it contrasts students' statements on holistic attention in their schooling and the selective focus of tutoring.

Table 2. Students' Comparisons of the Pedagogic Styles of Teachers and Tutors

\begin{tabular}{|c|c|}
\hline Teachers & Tutors \\
\hline Content & Skills for Examinations \\
\hline $\begin{array}{l}\text { School teachers focus mainly on content } \\
\text { knowledge. They don't have enough time } \\
\text { to finish the syllabus, let alone } \\
\text { [examination] skills. Only a few teachers } \\
\text { teach us skills. }\end{array}$ & $\begin{array}{l}\text { Private tutors talk more about the } \\
\text { examination skills, and they can guess } \\
\text { examination questions. Some important } \\
\text { tips are given [by tutors]. }\end{array}$ \\
\hline $\begin{array}{l}\text { We have school-based assessment which } \\
\text { takes up much of our time. Teachers do } \\
\text { not have enough time to teach us } \\
\text { [examination] skills. }\end{array}$ & $\begin{array}{l}\text { The tutoring centres particularly focus on } \\
\text { exam skills. They teach us how to get a } \\
\text { pass or high marks. }\end{array}$ \\
\hline $\begin{array}{l}\text { Teachers teach in a more comprehensive } \\
\text { way, such as reading newspaper. }\end{array}$ & $\begin{array}{l}\text { Tutors focus more on the skills to answer } \\
\text { exam questions and the criteria of } \\
\text { marking schemes. }\end{array}$ \\
\hline $\begin{array}{l}\text { I think teachers teach us knowledge. They } \\
\text { do not tell us how to memorize those } \\
\text { important points. Their teaching is not } \\
\text { enough for public exam demands. }\end{array}$ & $\begin{array}{l}\text { Tutors help me improve exam skills, such } \\
\text { as how to focus on key points for } \\
\text { memorisation, and how to approach time } \\
\text { management for exam papers. }\end{array}$ \\
\hline Holistic Attention & Selective Focus \\
\hline $\begin{array}{l}\text { I think teachers help us grow and develop in } \\
\text { different ways. They teach us attitudes for } \\
\text { life, and how to handle problems. Maybe } \\
\text { teachers miss out the time to teach, as they } \\
\text { have to go very fast to cover the syllabus. }\end{array}$ & $\begin{array}{l}\text { The tutors have exclusive attention to } \\
\text { exam skills. My tutor explains to me the } \\
\text { exam questions and formats, and teaches } \\
\text { me how I should respond to the } \\
\text { questions. With this support, I think }\end{array}$ \\
\hline
\end{tabular}


examination is not as harsh as I thought.

The teacher wants to finish the syllabus first, and then spend time to revise with us in preparation for exam. Time is never enough, and that is why she always speaks fast.

School teachers need to look after more students and more matters, so they might not have enough time for every student.

My teacher teaches me the full concepts with drawings. My basic knowledge is strengthened. However, many classmates do not see the relevance for examination.

Teachers teach you $120 \%$ for the exam [i.e. more than what is required for the exam]. So you need more time to study the $120 \%$ for the exam. It is hard work to study more in order to meet exam demands.
The tutors do not teach according to syllabus, but provide past exam papers and question types that are more diverse and more complicated than those provided by school teachers.

My tutor sets questions based on my ability. He also gives me many exercises, and explains what I do not understand. His teaching is easy to follow.

My tutor constantly raises questions for exam paper drilling. With strengthened knowledge from the teacher's help, my tutor helps me demonstrate better my knowledge for exam performance.

Basically if you learn from the tutors, you can have $90 \%$ of the questions that come out in the exam. Of course you want to spend less time on studying.

As noted, the quantitative data from the questionnaires showed that improvement of examination scores was the dominant motive for the vast majority of students who received tutoring. In line with this, the interview data indicated that many students sought tutoring because they felt that they did not receive enough focus on examination techniques from their teachers. Students who received tutoring tended to describe their teachers' focus as being on comprehensive knowledge while their tutors focused on preparation for examinations e.g. by identifying the questions likely to arise and ways to answer these questions. One attraction, which may be described as typical, was information on marking schemes and the promise of skills in memorisation and time management for examinations. School-based assessment was part of the reform strategy to alleviate the pressure of public examinations (Hong Kong Education Commission, 2000, 2006). Ironically, it was perceived by the students to consume so much school curriculum time that it reduced the ability of teachers to focus on the content for examinations.

A related pattern emerged from the students' remarks about the breadth of the content covered by the teachers. The students felt that the teachers were more concerned with wide-ranging knowledge and personal growth than with helping the students to handle the preparation for examination performance. By contrast, the tutors' pedagogy was again perceived to have a strategic focus on examinations. Teachers were seen to be responsible for covering the whole curriculum under time pressure; and when individual attention was not perceived to be available, students sought support from private tutoring. The dichotomy presented by one student in which teachers over-teach by $120 \%$ while the selective focus of tutors would cover $90 \%$ of the examination questions was another striking remark about the connection between learning and examinations. This student viewed the teachers' full labour in teaching the concepts for proper understanding as an inefficient approach to prepare for the examinations. Skills for examinations seemed to be prioritised over substantive learning and understanding. 


\section{Learning orientations}

The above remarks may be elaborated upon with further classification of interview responses. Table 3 presents students' remarks about learning attitudes and preferences in three groups with contrasting pairs: comprehensive coverage of the curriculum compared with remedial learning; structure and routines compared with space and personal relationships; and deeper learning needs compared with superficial learning needs.

Table 3. Students' Comparisons of Learning Orientations at School and in Tutoring

\section{Learning Orientations at School Comprehensive Coverage of the Curriculum \\ Even when our teachers want to teach a lot, we are not so cooperative. Our class is always noisy, so much time is spent on disciplinary problems. Then teachers have to catch up with the syllabus. \\ In school, we have to cover textbooks, and I am expected to do my exercises at home. I then find difficulty that I cannot cope. \\ My school teachers have too much to cover, and cannot attend to all the details. I am left with my weakness in grammar. \\ In school, we are expected to be taught everything, and teachers go through textbooks only once. However, I can't stop the teacher from time to time to clarify what I do not understand. \\ Schooling is like going through the whole chapter of a book.}

\section{Structure and Routines}

School lessons are boring, as we have to learn from textbooks all the time. Some classmates sleep during class. There are many lessons throughout the weeks. We get into a habit of not treasuring the class time.

Though teachers tell us that we can ask them if we have any questions, we know they are always very busy marking our homework. So we don't go to them for help.

Teachers are not available after school. I cannot easily seek help in school.
Learning Orientations in Tutoring Remedial Learning

Discipline problems do not arise because tutors leave us to do whatever we want to do. Time is spent on what we have not understood in school. Tutors do not worry about progress of our teaching syllabus.

In small groups, my tutors briefly teach us and give us some questions to do there. I receive personal explanation on my problems.

I do not need to cover too much content, but just focus on my weakness in grammar with worksheets and feedback.

We review what we are expected to show in exams. I like the tutorial more because I can stop my tutor and ask for explanation from time to time.

Attending tutorials is like focusing on certain sections of the chapter.

Space and Personal Relationships

Sometimes the content and the presentation skills of the tutor are funny, so I feel relaxed in tutorial classes. They stay with fashion, and the atmosphere is much more relaxing than in school.

My tutor answers all my questions. I also learn from my tutor the tricks of how to remember the difficult stuff in order to show in examination that I have learned them.

Tutorial centres can meet the youths' needs, as they know nowadays we like 
However, I like what I have learned from tutorials, so that I can answer my teacher's questions. My teacher may think that I have worked hard. I like to feel confident.

In school, I have to fit in the fixed structure of the lessons. The level is sometimes too easy for me, and at other times too difficult. The teachers are often too busy with many students, and they cannot give me individual attention.

\section{Deeper Learning Needs}

I need to be trained through a lot of exercises, and cannot easily understand simply from teachers' talking. I am also absent-minded, and need a lot of revisions. However, I receive little help that can meet my needs.

One of my friends is very attentive in class. Although he appears to learn slowly, he actually understands very clearly when he explains to me what he has learned.

In schools, we do not have star teachers. Often, we do not pay respect to good teachers. However, I do learn something long-term from different teachers that can be applied to daily life. online communications. Tutors can be contacted through online forum and Facebook. Sometimes they initiate activities to promote relationships.

For one-to-one tutoring, it is only you. You can ask any questions without feeling embarrassed. I like the tutor's flexibility to let me choose the type of work according to my ability. After all, I have paid to be taught what I need, and I feel more comfortable.

\section{Superficial Learning Needs}

The large-scale tutoring classes cannot meet my needs to clarify difficult concepts in Economics. However, I do attend them for training of general language skills. For instance, they teach us how to put brackets around clauses of important sentences.

I do not find any friends there in the tutorial centres. So it is boring to be there. To attend more classes after school makes me tired. I am going because I have to obey my parents.

The magic of star tutors is exaggerated. If you do not study hard, I do not think they can help you achieve a good grade. They only offer some supplementary learning opportunities.

The cultural environments in the two contexts are rather different when it comes to the notion of discipline in learning. The noise in school classrooms is a distraction for school teachers, and discipline for an expected norm of classroom behaviour becomes a central concern. Tutors do not usually have such discipline problems because the self-selected students attend with a sense of purpose. Teachers' responsibility to cover the entire curriculum poses another major contrast, since tutors can address remedial learning with clear targets on students' identified weaknesses. The remark that "school teachers have too much to cover, and cannot attend to all the details" portrays the tension that teachers have to operate within the time constraint for completing the curriculum. The contrast is captured in the analogy of schooling as going through the whole chapter of a book and tutoring as focusing on selected sections of the chapter. In this sense, the students seem to see learning in school as a requirement to fit the speed of the teachers, while the tutoring sessions can be perceived as better tailored.

The reports of experiences in the two settings have observable differences in the expected norms of behaviour. At a less visible level, differences can be rooted in the ways that students relate to teachers and to tutors. Beyond the logistics of curriculum coverage, teachers engage in routines such as design of homework, grading, and dimensions of administration which are not necessarily appreciated by students. Yet 
students seem to lack a channel to voice their needs and sustain co-working relationships. Even when there is a proclaimed channel through which students are invited to ask questions, many students do not use it because they perceive teachers to be too busy in and out of class. The question is not so much about whether teachers should abandon their sound intentions, but more about how teaching and learning can be more closely articulated through teachers' awareness of students' preferred learning styles. The distance between teachers and students is a deeper environmental issue as a possible outcome of weak bonding or disconnection between teaching and learning. The weak human bonding in schools helps explain how conflicts that are not resolved can turn into mutual disrespect and further neglect of learning needs. In this situation, students who can afford it are likely to turn to private tutoring as an alternative.

Nevertheless, private tutoring does not seem to be a ready-made solution to unresolved issues of discipline in teaching-learning relationships. Tutors may help with "the tricks of how to remember the difficult stuff" for examinations, but this does not necessarily address more fundamental learning challenges. Payment to be taught what is personally needed becomes the legitimate means to tackle the perceived difficulties.

Learning needs are mentioned by some students, but most remarks are of lower order and focus on such matters as exercises and revision. Underpinning these remarks is a cry for a sense of progress and achievement amidst endless listening to teacher talk and routine chores. None of the statements displays a hankering for exploration and creativity. Perhaps the interview respondents have never developed a schema to understand different levels of learning needs, and the sample may be dominated by students who seek the kind of tutoring that trains dependency. One student admired a friend who "appears to learn slowly" but "actually understands very clearly" as a result of being very attentive in class. This statement invites further thought about what makes a student attentive to achieve slow learning when most teachers expect students to learn at the speed of the teachers' delivery.

In parallel, none of the statements about tutoring shows signs of deep learning. Rather, the statements are about the presentation of examination drills and a relaxing atmosphere for revision of content knowledge. One sentiment about learning at school was noteworthy in the statement that "I do learn something long-term from different teachers that can be applied to daily life"; but few students had such deep orientations, and most students were willing to pay for extra lessons to meet superficial learning needs.

\section{The meaning of support}

Aspirations for learning cannot be ignited in school experiences when students are confronted with fear of being expected to learn too much within a short time. The more inadequate their perception of learning orientations to respond to fast-track delivery from teachers, the more the fear emerges. It is therefore natural for students to feel a need for quick solutions. The market offers all kinds of quick solutions to problems that may not have been clearly defined.

If learning is recognised as a journey of discovery, including episodes of deep struggle, the necessary support to meet various stages of learning needs is not about replacement of difficulties with either an impression of comfort or a false sense of progress and display of outcomes. Effective support must be solicited and provided in response to the learners' own drive for learning. Teachers or tutors, when committed 
to facilitation of learning, can offer appropriate support according to their awareness of the students' learning needs. The discourse on diversity of learning needs must go beyond the perception of variation among learners. It should consider small bites as well as holistic views, individuals as well as large classes, exploration as well as basic mastery of skills, and critical reflection as well as factual information.

Whether in school or in private tutoring, students cannot escape from the ownership of learning problems at a personal level if solutions are to be reached. Yet, a dominant view of inadequate schooling leading to subscription to private tutoring can overlook the problem without confronting the continuum of living up to learning demands. Discourses on the drive for achievement or success can be a further powerful denial of authentic learning processes. Teachers and tutors can, at worst, share deceitful claims of teaching and tutoring while abandoning the meaning of support much needed for a true sense of learning progress and achievement.

Too often, examinations are mistakenly targeted as the source of pressure taking away learning space, and both teachers and tutors are tempted to avoid recognition of a natural gap between teaching/tutoring and learning. Such neglect can lead to a distortion of learning that aggravates the fear of difficulties under the pressure of examinations. Assessment of learning through examinations then paradoxically becomes a heavy demand to be served at the cost of learning. When such distortion continues for the mass of fearful learners, new lenses may help to decode the relationships between mainstream schooling and private supplementary tutoring.

To probe more deeply into the meaning of support, a metaphorical approach may help to expose issues for further investigation. For many students who seek private tutoring, it is likely that teachers in the public school system of free education for all are seen to adopt a delivery approach to teaching without adequate space to address diverse learning needs. In a sense, school teachers are comparable to bus drivers who proclaim to drive all passengers (students in free education) to the set destinations (curriculum coverage). By focusing on curriculum areas with the intention to cover all the content, teachers may not be able to attend to whether and how students of diverse learning needs are responsive to the timing and speed of coverage. The sense of coverage, if becoming a dominant way to implement curriculum for examination preparation, is somewhat like a bus driver focusing on driving to the destination at a speed calculated to cover the journey under the time constraint, with little regard to whether passengers are on board (i.e. cognitively present in the classroom) or willing to share all parts of the journey as scheduled (i.e. ready to learn at a common pace with the given pedagogic style). The missing passengers are like students with parents who are so concerned with learning difficulties or competitiveness of their children that they are ready to invest in private tutoring for remedial learning or enhancement of performance. Private tutoring is like a transportation service operating in parallel to the main one with explicit claims of promises to take passengers to their destinations. Such an analogy may help to reveal the motives for seeking additional help beyond mainstream schooling. It does not fully reflect the complexity of the relationship between free education and supplementary tutoring, but it poses a question whether parents and/or students are aware of their specific needs when subscribing to a paid service. Where are the tutors taking the students who are like passengers not able or willing to travel by the free bus? Are students' learning capacities enhanced to benefit from the public system, or are they simply taught to be increasingly dependent? What are the costs beyond the financial ones from having to take the parallel service in addition to being physically present in the main service but perhaps disengaged from its processes? 
In some scenarios, self-awareness of learning needs is not taken as having so much importance as the mere sense of subscribing to support in the hope that some needs may be met along the way. Mixing the analogy with the reality, there emerge multiple possibilities. Some students and parents may simply subscribe to the privatetutoring vehicles in the hopes that the supplementary journeys will compensate for vaguely-defined shortcomings. Others may join the private-tutoring vehicles even though they have no real need for them but observe that many other people are taking the private-tutoring vehicles and fear missing something that could be useful even at the cost of time for leisure and other activities. Others, knowing that they will have the back-up support of the private-tutoring vehicles, may reduce their efforts to benefit from the free bus service, and perhaps may even distract the learning of their fellow passengers, thereby enlarging the number of drop-out passengers. As a result, the learning in the initial bus journey becomes inefficient - and demand for the private-tutoring vehicles grows further. The desirable destination for enhanced capacity for independent learning gives way to vague notions of curriculum coverage and supplementary assistance for such coverage.

\section{Conclusions}

This paper has focused on relationships between mainstream schooling and private supplementary tutoring from the perspectives of Hong Kong secondary school students. Teachers may or may not be well informed about their students' desires and needs. In any case, private tutoring offers to bridge at least some gaps, though it does not always do so effectively.

The commentary should be viewed in the context of wider educational reform. As mentioned above, structural change in the post-colonial era led to the first Hong Kong Diploma of Secondary Education (HKDSE) examination in 2012. The structural change was accompanied by laudable goals of "a learning environment that will induce students to be curious, to question and to explore", and a system that would give students "the opportunity to exhibit their abilities in independent thinking and creativity, and thus nurture more creative talents" (Hong Kong Education Commission, 2000, p. 34). The most comprehensive aim was about holistic education, "to enable every student to achieve all-round development according to his/her own attributes”, with "no loser” (Hong Kong Education Commission, 2000, p. 36).

This framework matched internationally-oriented documents, some of which had distinguished pedigrees. For example, the Hong Kong reform was in tune with UNESCO's 1972 report entitled Learning to be. This report stated (Faure, 1972, p. vi) that: "The aim of development is the complete fulfilment of man, in all the richness of his personality, the complexity of his forms of expression and his various commitments”. The theme was developed in Delors' (1996) Report, which identified four pillars of education - learning to know, learning to do, learning to live together, and learning to be. Revisiting educational aims is crucial for identifying the destinations for the journey of schooling and associated activities, including private tutoring. It is important to recognise the natural gap between aspirations and part of the reality that this paper has identified. Journeying to reach educational aims demands partnership from all stakeholders. The significance of such a process was articulated by Sterling (2001, p. 8) as "continuous re-creation or co-evolution where both education and society are engaged in a relationship of mutual transformation".

By considering students' voices, this paper has revealed how well-intentioned topdown plans for innovation may be subverted by conflicting expectations and the 
divergent agendas of students, tutors and teachers. Only when learning gaps are recognised by stakeholders can they be addressed. When teachers have to manage competing demands, their challenge is much more than time management, and includes a sense of priority to be involved in education of students with an open channel for building teaching-learning connectivity. Reception to students' voices commonly reveals the gap between teachers' intentions and students' readiness, thus exposing the space for critical learning. Students may hanker for private tutoring to meet their needs, but the learning gap may be situated in the distance between their learning orientation (attitudes and skills) and perceptions of the solutions to their learning problems. Tutoring can sometimes resolve the problem, but does not always do so. At worst, tutoring can exacerbate problems, not only because many tutors are untrained but also because some commercial operators seek to inculcate a sense of dependence.

While of course the sample addressed in this paper cannot fully represent the whole of Hong Kong's student population, it is reasonably representative of students in the senior secondary level. Similar remarks apply to the teachers whom these students are commenting on. Teachers are often expected to be change agents for reform, but failure of reforms is common if too much weight is placed on the teachers. As observed by Kennedy (2005, pp. 231-233), teachers have dispositions that interfere with their ability to implement reforms; and often the circumstances of teaching prevent teachers from altering their practices. This study suggests that teachers' accountability to students may have been eroded amidst other competing priorities. In a powerful narrative about learner-centred education as a global phenomenon, Schweisfurth (2013, pp. 153-154) concludes that research evidence paints a picture of failure and waste, particularly where hope and development are needed most. More positively, a great deal can be accomplished when the key challenges are clearly identified and both teachers and students are given the necessary support in an open atmosphere.

The paper commenced by noting that private tutoring has long been visible in much of East and South Asia, but that researchers have been slow to focus on the phenomenon. Hong Kong is among the societies with particularly high rates of tutoring, but the phenomenon is growing rapidly in all parts of the world (Bray, 2009; Mori \& Baker, 2010). Educators elsewhere might find it beneficial to look at patterns in Hong Kong in order to comprehend the challenges and adopt appropriate policies for their own settings. To date, little research in any location has addressed the sorts of pedagogical and learning dimensions that have been the focus of this paper. While Hong Kong has distinctive characteristics arising from its economic and social structures, investigation of the relationships between mainstream schooling and private supplementary tutoring in other locations would probably reveal striking parallels.

Acknowledgement: The research reported in this paper was funded by the General Research Fund (GRF) of the Hong Kong Research Grants Council (RGC), project 741111. Team members included Chad Lykins, Emily Mang, Wang Dan and Zhan Shengli. The authors also specifically acknowledge assistance from Nutsa Kobakhidze. 


\section{References}

Aslam, M. \& Atherton, P. (2014). The shadow education sector in India and Pakistan: Opening Pandora's box. In I. Macpherson, S. Robertson \& G. Walford (Eds.), Education, privatisation and social justice: case studies from Africa, South Asia and South East Asia (pp.139-158). Oxford: Symposium.

Aurini, J., Davies, S. \& Dierkes, J. (Eds.) (2013): Out of the shadows: The global intensification of supplementary education. Bingley: Emerald.

Bray, M. (1999). The shadow education system: Private tutoring and its implications for planners. Paris: UNESCO International Institute for Educational Planning (IIEP).

Bray, M. (2009). Confronting the shadow education system: What government policies for what private tutoring? Paris: UNESCO International Institute for Educational Planning (IIEP).

Bray, M. (2013). Benefits and tensions of shadow education: Comparative perspectives on the roles and impact of private supplementary tutoring in the lives of Hong Kong students. Journal of International and Comparative Education, 2, 18-30.

Bray, M., Mazawi, A. E. \& Sultana, R. G. (Eds.) (2013). Private tutoring across the Mediterranean: Power dynamics and implications for learning and equity. Rotterdam: Sense Publishers.

Burch, P. (2009). Hidden markets: The new education privatization. New York: Routledge.

Dawson, W. (2010). Private tutoring and mass schooling in East Asia: Reflections of inequality in Japan, South Korea, and Cambodia. Asia Pacific Education Review, 11, 14-24.

Delors, J. (1996). Learning: The treasure within. Paris: UNESCO.

Dohmen, D., Erbes, A., Fuchs, K., \& Günzel, J. (2008). What do we know about tutoring? Progress report and evaluation of the research literature on supply, demand and effects. Berlin: Institute for Education and Socio-Economic Research and Consulting. http://www.bmbf.de/pub/sachstand_nachhilfe.pdf [in German].

Faure, E. (1972). Learning to be: The world of education today and tomorrow. Paris: UNESCO.

Hamid, O., Sussex, R. \& Khan, A. (2009). Private tutoring in English for secondary school students in Bangladesh. TESOL Quarterly, 43, 281-308.

Hemachandra, H.L. (1982). The growing phenomena of tuition classes: The perceived reasons and some latent social factors. Sri Lanka Journal of Social Sciences, 5(2), 39-69.

Henrard, V. (2011). Income inequality and public expenditure on social policy in Hong Kong. Hong Kong: Civic Exchange.

Ho, E.S.C. (2012). Student learning assessment. Bangkok: UNESCO Asia and Pacific Regional Bureau for Education. Retrieved from http://unesdoc.unesco.org/ images/0021/002178/217816E.pdf.

Hong Kong Education Commission (2000). Learning for life, learning through life: Reform proposals for the education system in Hong Kong. Hong Kong: Education Commission. Retrieved from http://www.e-c.edu.hk/eng/reform/rf1.html.

Hong Kong Education Commission (2006). Learning for life, learning through life: Progress report on the education reform (4). Hong Kong: Education Commission. Retrieved from http://www.e-c.edu.hk/eng/reform/Progress\%20Report\%20(Eng)\% 202006.pdf. 
Hong Kong Census \& Statistics Department. (2012). 2011 Census thematic report: Ethnic minorities. Hong Kong: Census \& Statistics Department. Retrieved from statistics.gov.hk/pub/B11200622012XXXXB0100.pdf

Hong Kong Information Services Department (2013). Hong Kong 2012. Hong Kong: Information Services Department. Retrieved from http://www.yearbook.gov.hk/ 2012/en/index.html.

Kennedy, M. (2005). Inside teaching: How classroom life undermines reform. Cambridge: Harvard University Press.

Kwo, O. (2010). Teachers as learners: A moral commitment. In O. Kwo (Ed.), Teachers as learners: Critical discourse on challenges and opportunities (pp. 313333). Dordrecht: Springer, and Hong Kong: Comparative Education Research Centre, The University of Hong Kong.

Kwo, O. \& Bray, M. (2011). Facing the shadow education system in Hong Kong. IIAS Newsletter (University of Leiden, International Institute for Asian Studies), 56, 20. Retrieved from http://www.iias.nl/article/facing-shadow-education-system-hongkong.

Kwok, P. (2001). Local knowledge and value transformation in East Asian mass tutorial schools. International Education Journal, 2, 86-97.

Kwok, P. (2004). Examination-oriented knowledge and value transformation in East Asian cram schools. Asia Pacific Education Review, 5, 64-75.

Marimuthu, T., Singh, J. S., Ahmad, K., Lim, H. K., Mukherjee, H., Oman, S., Chelliah, T., Sharma, J.R., Salleh, N.M., Yong, L., Leong, L.T., Sukarman, S., Thong, L.K., \& Jamaluddin, W. (1991). Extra-school instruction, social equity and educational quality. Singapore: International Development Research Centre.

Modern Education Group Limited (2011). Global offering. Hong Kong: Modern Education Group Limited.

Mori, I. \& Baker, D. (2010). The origin of universal shadow education: what the supplemental education phenomenon tells us about the postmodern institution of education. Asia Pacific Education Review, 11, 36-48.

Odhiambo, J. (2009). Effects of remedial lessons on academic achievement of students in public secondary schools in Nairobi West District, Kenya. MEd dissertation, Catholic University of Eastern Africa.

People's Republic of China. (2010). Outline of China's national plan for medium and long-term education reform and development (2010-2020). Beijing: Ministry of Education. Retrieved from http://www.moe.edu.cn/publicfiles/business/htmlfiles/ moe/s3501/index.html.

Salili, F. (1996). Accepting personal responsibility for learning. In D. A. Watkins \& J. B. Biggs (Eds.), The Chinese learner: Cultural, psychological and contextual influences (pp. 85-105). Hong Kong. Comparative Education Research Centre, The University of Hong Kong.

Schweisfurth, M. (2013). Learner centred education: Whose pedagogy for whose development? London: Routledge.

Silova, I., Būdienè, V. \& Bray, M. (Eds.) (2006). Education in a hidden marketplace: Monitoring of private tutoring. New York: Open Society Institute.

Sterling, S. (2001). Sustainable education: Re-visioning learning and change. Totnes: Green books for the Schumacher Society.

Stevenson, D. L. \& Baker, D. P. (1992). Shadow education and allocation in formal schooling: Transition to university in Japan. American Journal of Sociology, 97, 1639-1657.

Synovate (2011). Market landscape for private tuitions in Hong Kong and English 
learning institutes in China. Hong Kong: Synovate.

United Nations (1948). Universal declaration of human rights. New York: United Nations.

Verger, A.L. \& Robertson, S. (2012). The GATS game-changer: International trade regulation and the constitution of a global education marketplace. In S. L. Robertson, K. Mundy, A. Verger, \& F. Menashy (Eds.), Public private partnerships in education: New actors and modes of governance in a globalizing world (pp. 104-127). Cheltenham: Edward Elgar.

Zeng, K. (1999). Dragon gate: Competitive examinations and their consequences. London: Cassell.

Zhan, S., Bray, M., Wang, D., Lykins, C. \& Kwo, O. (2013). The effectiveness of private tutoring: Students' perceptions in comparison with mainstream schooling in Hong Kong, Asia Pacific Education Review, 14, 495-509. 